\title{
Peran Wisdom terhadap Life Satisfaction pada Lansia
}

\author{
Aisah Indati ${ }^{1}$, Maria Goretti Adiyanti ${ }^{2}$, E Neila Ramdhani ${ }^{3}$ \\ Fakultas Psikologi Universitas Gadjah Mada
}

\begin{abstract}
Life-satisfaction is an important thing for the elderly. Elderly with all its problems such as a decrease in physical, psychological, and social conditions can feel a decrease in life satisfaction. Decrease in life satisfaction may be avoided if the elderly have a high level of wisdom. This study aimed to see the contribution of wisdom to the life-satisfaction of the elderly people. The research subjects were 65 elderly people aged 60 years and over in Yogyakarta. Data retrieval was done using the adaptation of 3D-WS Ardelt (2003) scale to measure wisdom and the translation of Life Satisfaction Index Z Neugarten scale (1961) to measure life satisfaction levels. Research data were analyzed using regression analysis. The analysis found that the affective dimension of wisdom was a significant predictor of life satisfaction in elderly $(b=0.540 ; p=0.003)$.
\end{abstract}

Keywords : elderly; life satisfaction; wisdom

Abstrak. Life-satisfaction (kepuasan hidup) merupakan hal yang penting bagi lansia. Lansia dengan segala permasalahnya seperti penurunan kondisi fisik, psikologis, dan sosial dapat merasakan penurunan kepuasan hidup. Penurunan kepuasan hidup mungkin dapat dihindari jika lansia tersebut memiliki tingkat wisdom atau kearifan yang tinggi. Penelitian ini ingin melihat peran kebijaksanaan terhadap life satisfaction lansia. Subjek penelitian berjumlah 65 lansia berusia 60 tahun ke atas di Yogyakarta. Pengambilan data akan dilakukan menggunakan skala adaptasi 3D-WS (Three-Dimensional Wisdom Scale) Ardelt (2003) untuk mengukur tingkat wisdom dan skala terjemahan Life-satisfaction Index Z Neugarten (1961) untuk mengukur tingkat life satisfaction. Data penelitian dianalisis menggunakan analisis regresi. Hasil analisis menemukan bahwa dimensi afektif dari wisdom merupakan prediktor yang signifikan terhadap life satisfaction pada lansia $(b=0,540 ; p=0,003)$.

Kata kunci : kearifan; kepuasan hidup; lansia

Usia tua sering disebut sebagai masa lanjut usia. Masa lanjut usia merupakan tahapan paling akhir dari perjalanan hidup manusia. Proses menjadi tua selain merupakan proses perkembangan yang terus berlangsung hingga akhir hidup manusia, juga ditandai adanya kemunduran secara fisik, psikis dan sosial. Datangnya usia lanjut dalam rentang kehidupan manusia menciptakan keterbatasan dalam ruang lingkup gerak hidupnya. Seorang wanita yang memasuki masa lanjut usia akan mengalami hal yang sama yaitu adanya keterbatasan dalam ruang lingkup gerak hidupnya. Trief, Michael, Pine, dan Weinstock (2003) menyatakan bahwa selain kemunduran secara fisik, stres dan pesimis, lanjut usia

\footnotetext{
1 Korespondensi mengenai isi artikel ini dapat dilakukan melalui aisah.indati@gmail.com

2 atau melalui adiyanti_psy@ugm.ac.id
} 
juga kehilangan kemampuan untuk bersosialisasi dan semangat hidup.

Wirakusumah (2002) menyatakan meskipun proses menua tidak dapat dihindari, tetapi masih dapat dikendalikan dengan mengatur gaya hidup dan kondisi lingkungan yang mendukung seseorang untuk selalu tampil prima, artinya bukan berarti lanjut usia tidak bisa mencapai kualitas hidup atau tidak dapat menikmati hari tuanya secara produktif, karena pada kenyataannya banyak dijumpai lanjut usia yang masih sehat baik secara fisik maupun psikis mempunyai kemampuan yang tidak kalah dengan mereka yang masih muda. Artinya untuk mencapai hidup yang berkualitas bagi lanjut usia bukan hal yang tidak mungkin.

Usia tua digambarkan sebagai masa penurunan kemampuan fisik, tetapi dari segi emosi dikatakan bahwa usia tua justru memiliki kontrol diri yang lebih baik daripada orang muda. Emotional maturity merupakan keadaan atau kondisi ketika seorang individu mencapai tingkat kedewasaan dari perkembangan emosi (Saul \& Pulver, 1965). Selanjutnya ditemukan hasil bahwa umur diasosiasikan dengan pengurangan intensitas impuls emosi. Seiring dengan berkurangnya signal yang keluar dari ekspresi emosi yang positif ataupun negatif dan meningkatnya kontrol emosi. Terlihat adanya perbedaan pola korelasi antar usia dan respon emosi. Penuaan diasosiasikan dengan menurunnya pengalaman emosi terhadap kemarahan, kesedihan, dan ketakutan dengan peningkatan pengalaman kebahagiaan.

Suatu populasi dikatakan memasuki era "aged" atau menua jika proporsi penduduk yang berusia di atas 60 tahun lebih dari $10,0 \%$. Saat ini sudah terjadi penuaan global serta penuaan penduduk. Terdapat lebih dari 600 juta penduduk berusia 60 tahun ke atas. Mayoritas lansia tinggal di negara berkembang, seperti
Indonesia, dan lain-lain. Di Asia dan Pasifik, populasi lanjut usia semakin meningkat dengan pesat, dari 410 juta pada tahun 2007 diperkirakan menjadi 733 juta pada tahun 2025, dan akan terus meningkat menjadi 1,3 milyar pada tahun 2050. Secara proporsi, populasi lanjut usia akan mencapai $15 \%$ dari total populasi secara keseluruhan pada tahun 2025. Angka tersebut akan meningkat terus menjadi $25 \%$ pada tahun 2050. Indonesia secara proporsi, akan menempati peringkat ke-enam (Badan Pusat Statistik, 2010). Dengan semakin tingginya usia harapan hidup maka perlu adanya penanganan yang serius bagi lansia baik masalah fisik, psikologis, maupun sosial.

Berkaitan dengan penanganan dari segi sosial maka diperlukan adanya sebuah lembaga sosial yang menangani masalah lanjut usia. Lembaga sosial tersebut harus dapat menjangkau lansia pada lapisan paling bawah, maka disitulah terlihat pentingnya keberadaan posyandu (pos pelayanan terpadu) untuk lansia. Didalamnya terdapat kader-kader lansia yang tentunya harus memiliki bekal pengetahuan mengenai lansia.

Ada dua permasalahan utama dengan terjadinya penuaan pada manusia, yaitu masalah fisik dan masalah kejiwaan (psikologis). Secara psikologis ada tiga masalah utama yang muncul pada proses penuaan yaitu demotivasi, menarik diri dan loneliness. Pada masalah pertama, lansia kehilangan motivasi atau gairah untuk berkarya karena merasa apa yang dilakukannya tidak berguna atau tidak akan dihargai oleh orang lain. Selanjutnya lansia akan menarik diri dari pergaulan, bisa karena merasa rendah diri, kecewa atau malu. Hal ini akan membuat lansia merasa kesepian, sendirian dan merasa dikucilkan oleh masyarakat (Azwar, 2013).

Bagi lansia sendiri, banyaknya masalah-masalah dari dalam dan luar diri membutuhkan cara untuk mensikapi 
masalah tersebut sehingga bagi lansia yang bijaksana diharapkan dapat mengatasi permasalahan dengan baik. Lansia yang wise akan dapat menikmati kepuasan hidup meskipun ditengah permasalahan yang sedang dihadapi.

Permasalahan di atas menimbulkan pertanyaan, bagaimanakah lansia akan menghadapi permasalahan tersebut, apakah akan dihadapi secara bijaksana atau tidak, dan bagaimana kaitannya dengan life satisfaction yang lansia rasakah. Penelitian ini ingin melihat seberapa jauh peran wisdom terhadap life satisfaction pada lansia.

Life satisfaction (kepuasan hidup)

Life satisfaction (kepuasan hidup) merupakan salah satu konsep yang dianggap mencerminkan sebuah kondisi kehidupan yang baik atau a good life. Terdapat dua konsep terkait dengan life satisfaction yaitu kualitas hidup (quality of life) dan kesejahteraan subjektif (subjective well-being). Kualitas hidup sering digunakan untuk menggambarkan kehidupan yang baik dalam berbagai bidang ilmu seperti ekonomi, sosial, psikologi, dan kesehatan (Berg, 2008).

Neugarten, Havighurst, dan Tobin (1968) menjelaskan bahwa life satisfaction lansia ditunjukan oleh perasaan sejahtera yang mencerminkan kesesuaian antara cita-cita masa lalu dan dengan kondisi kehidupan sekarang. Diener, Emmons, Larsen dan Griffin (1985) mendefinisikan life satisfaction sebagai sebuah penilaian global secara kognisi dari hidup seseorang yang mungkin dipengaruhi oleh afeksi. Hurlock (1999) mengatakan life satisfaction adalah keadaan sejahtera dan adanya kepuasan hati yang merupakan kondisi yang menyenangkan yang timbul bila kebutuhan dan harapan tertentu individu terpenuhi. Santrock (2002) menjelaskan kesejahteraan psikologis ( $p$ sychological wellbeing) adalah kepuasan hidup atau kepuasan terhadap kehidupan secara keseluruhan. Disimpulkan bahwa life satisfaction digunakan secara luas sebagai index kesejahteraan psikologis pada orang lanjut usia.

Neugarten, Havighurst, dan Tobin (dalam Monks dan Haditono, 2004) melakukan serangkaian studi untuk melihat aspek-aspek life satisfaction. Kesimpulan dari beberapa studi tersebut adalah bahwa terdapat lima aspek life satisfaction yaitu: kesenangan, keteguhan hati, kesesuaian antara keinginan dan keberhasilan mencapai keinginan, konsep diri positif, dan suasana hati.

Life satisfaction merupakan aspek kognitif dari subjective well-being yang di kemukakan oleh Diener et al. (1985), disamping aspek afektif yaitu afek positif dan afek negatif. Selanjutnya Diener, Suh, Lucas dan Smith (1999) juga menyebutkan dua jenis life satisfaction yaitu global life satisfaction dan domain satisfaction. Global life satisfaction didefinisikan sebagai evaluasi individu terhadap hidupnya secara keseluruhan sedangkan domain satisfaction merupakan kepuasan individu yang spesifik pada setiap area dalam hidup.

Domain satisfaction menurut Diener et al. (1999) meliputi kepuasan dalam lingkup kerja (work), keluarga (family), dalam pengisian waktu luang (leisure), kesehatan (health), keuangan (finance), self, dan keterlibatan dalam kelompok (one's group). Sedangkan menurut Ardelt (1997) terdapat domain satisfaction pada lanjut usia meliputi beberapa area yaitu kondisi rumah, tetangga/lingkungan tempat tinggal, kondisi pensiun, pekerjaan setelah pensiun, situasi keuangan, kesehatan, aktivitas kelompok, kondisi pernikahan dan pengambilan keputusan dalam pernikahan, study child, cara anak mengasuh cucu, dan kunjungan anak. Brown, Bowling dan Flynn (dalam Sirgy, 2012) membagi domain satisfaction lansia pada beberapa area yaitu kesehatan, 
hubungan dalam keluarga, hubungan dengan orang lain, independensi, mobility, otonomi, aktivitas sosial dan pengisian waktu luang, keuangan (standard of living), kesejahteraan emosional, dan keagamaan atau spiritualitas.

Greenly, Greenberg, dan Brown (dalam Sirgy, 2012) menyebutkan beberapa domain satisfaction yang meliputi kondisi hidup, keuangan, pengisian waktu luang, keluarga, kehidupan sosial, kesehatan, dan akses untuk layanan kesehatan.

Dari beberapa pendapat ahli diatas dapat disimpulkan bahwa life satisfaction pada lansia meliputi kesehatan, hubungan dalam keluarga, hubungan dengan orang lain, independensi, mobility, otonomi, aktivitas sosial dan pengisian waktu luang, keuangan, kesejahteraan emosional, dan keagamaan atau spiritualitas.

Faktor-faktor yang mempengaruhi life satisfaction lansia berdasarkan beberapa hasil penelitian antara lain finansial, kesehatan, gaya hidup yang aktif, jaringan sosial, pertemanan dan keluarga, kepribadian, emosi positif, dan koping proaktif.

Sirgy (2012) merangkum penelitianpenelitan mengenai faktor-faktor yang berperan terhadap subjective well-being lansia. Rangkuman tersebut mencakup fakor-faktor yang berhubungan dengan life satisfaction lansia yaitu diantaranya faktor kesehatan (misalnya penyakit yang diderita dan kualitas layanan kesehatan lansia), faktor psikologis (nilai-nilai yang dalam diri individu seperti keterbukaan dengan pengalaman dan individualisme), faktor sosial (seperti status pernikahan, kualitas hubungan sosial, partisipasi dalam kegiatan sosial, dukungan sosial dari cucu), faktor sosial ekonomi (misalnya kondisi finansial), dan faktor tempat tinggal (tinggal bersama dengan anggota keluarga berbeda generasi lebih baik bagi kesejahteraan psikologis dibandingkan tinggal dengan keluarga satu generasi).

Disimpulkan bahwa life satisfaction pada lansia adalah kondisi sejahtera yang direfleksikan dengan perasaan bahagia terhadap kehidupan yang dijalani.

\section{Wisdom (kearifan)}

Wisdom (kearifan) memiliki beberapa pengertian dan tidak ada definisi yang tepat. Apakah wisdom bersifat intelektual, emosional, spiritual atau ketiganya? Apakah orang menjadi lebih bijaksana bersamaan dengan bertambahnya usia? (Papalia, Olds, \& Feldman, 2007). Pendekatan lain mengatakan bahwa wisdom sebagai aspek perkembangan kepribadian pada masa akhir kehidupan. Beberapa teori dengan menggunakan perspektif yang lebih kontekstual menggambarkan wisdom sebagai kemampuan kognitif. Ahli lain melihat wisdom sebagai sebuah integrasi dari intelektual dan emosi. Pendekatan lain yang berakar pada filsafat timur memfokuskan wisdom sebagai domain spiritual.

Penelitian yang dilakukan oleh Jeste et al. (2010) bertujuan untuk menemukan consensus dari para ahli mengenai ciri-ciri wisdom dengan menggunakan metode Delphi. Dari 57 pakar yang dihubungi melalui email, 30 orang bersedia mengikuti survei. Kebanyakan pakar sepakat bahwa wisdom memiliki sifat yang unik, merupakan perkembangan kognitif dan emosi pada tingkat yang lebih tinggi yang berasal dari pengalaman panjang, kualitas pribadi, dan bisa dipelajari. Sedangkan penelitian oleh Glück dan Bluck (2011) yang bertujuan untuk mendapatkan pandangan orang-orang awam (non-ahli) mengenai makna wisdom dengan responden 1.955 menunjukan hasil bahwa wisdom dinilai menurut cara pandang masing-masing individu, konteks individu tersebut, serta pada tahap apa individu 
tersebut berada ketika mengikuti penelitian, sehingga hasil yang didapat sangat beragam.

Penelitian oleh Asadi, Amiri, Molavi, dan Noaparast (2012) bertujuan untuk melihat tingkat kearifan dalam kelompok usia menggunakan skala 3D-WS. Kelompok-kelompok usia tersebut adalah 1) 15-17 tahun sebanyak 108 orang, 2) 19-23 tahun sebanyak 79 orang, 3) 25-35 tahun sebanyak 87 orang, 4) 40-50 tahun sebanyak 31 tahun, 5) 55-65 tahun sebanyak 40 orang. Hasilnya menunjukan bahwa usia memberi pengaruh secara signifikan terhadap wisdom, terutama pada dimensi reflektif dan afektif.

Stenberg (1986) melakukan penelitian yang bertujuan ingin melihat apakah kecerdasan, wisdom, dan kreativitas memiliki keterkaitan satu sama lain. Hasil menunjukan secara umum kecerdasan memiliki hubungan yang paling erat dengan wisdom. Sedangkan kecerdasan dan kreativitas menunjukan hubungan erat yang kedua, serta wisdom dan kreativitas tidak memiliki hubungan yang kuat. Hasil ini mendukung hasil penelitian Ardelt (2005) bahwa dalam wisdom terdapat dimensi kognitif, disamping dimensi reflektif dan afektif.

Erikson (1959), wisdom merefleksikan suatu kematangan yang memperhatikan kebaikan kolektif yang lebih penting dari kepentingan personal. Erikson (1959) mengembangkan teori tentang seberapa besar dampak lingkungan sosial terhadap perkembangan psikologis individu.

Birren dan Svensson menyebut wisdom sebagai sifat yang sangat luas dari fungsi mental tingkat tinggi. Teori eksplisit yang diterapkan terhadap wisdom berkaitan dengan teori-teori awal tentang kepribadian Erikson dan perkembangan kognitif Piaget atau teori yang menekankan aplikasi pengetahuan pragmatik dalam pencarian fungsi manusia yang luas biasa. Menurut Snyder dan Lopez (2007), ahli teori perkembangan yang berpengaruh, seperti Piaget, Jung, dan Erikson memberikan kerangka dasar bagi para teoretisi wisdom abad ke-20. Jalinan teoretis ini lebih lanjut diantaranya dipahami dari pandangan ahli teori perkembangan masa-hidup (life-span), misalnya Erikson (1959), yang memandang wisdom sebagai bagian dari perkembangan yang optimal.

Wisdom berdasarkan temuan Ardelt (2003) mencakup tiga dimensi yaitu 1) kognitif, 2) afektif, dan 3) reflektif. Dimensi kognitif meliputi pemahaman tentang pemaknaan hidup dan keinginan untuk mengetahui kebenaran, yaitu untuk memahami arti dan makna. Terkait dengan fenomena dan peristiwa, terutama dengan yang berhubungan dengan intra dan interpersonal. Meliputi akan kemampuan pengetahuan dan proses penerimaan.

Dimensi afektif berkaitan dengan kemampuan yang meliputi empati dan rasa saling menyayangi yang disertai dengan motivasi untuk menjaga perasaan orang lain membutuhkan transendensi selfcenteredness. Sedangkan dimensi reflektif merupakan persepsi terhadap suatu fenomena dan kejadian-kejadian dari berbagai perspektif, serta menghindari penilaian subjektif. Membutuhkan selfexamination, self-awareness, dan self-insight.

Berdasarkan pendapat-pendapat di atas dapat disimpulkan bahwa wisdom pada lansia adalah satu kondisi dimana seseorang itu memiliki integrasi antara aspek kognitif, reflektif, dan afektif yang dipengaruhi oleh berbagai faktor antara lain kematangan emosi, penyesuaian diri maupun dukungan sosial.

\section{Dinamika wisdom dan life satisfaction}

Bergsma \& Ardelt (2012) pernah meneliti mengenai hubungan antara wisdom dan kebahagiaan (happiness). Hasilnya menunjukan bahwa dimensi-dimensi wisdom berhubungan positif dengan 
kebahagiaan (diukur dengan dua single item), dengan korelasi paling kuat pada dimensi reflektif. Skor total wisdom berhubungan signifikan (positif dan moderat) dengan skor total kebahagiaan (wisdom juga menjelaskan $9 \%$ varians kebahagiaan). Dalam pembahasaannya disimpulkan bahwa kebahagiaan hedonik dan wisdom adalah dua hal yang saling berhubungan dan tidak bertentangan. Hal ini menampik pandangan bahwa individu yang memiliki wisdom menjadi cenderung tidak bahagia.

Jauh sebelum penelitian tersebut, Ardelt (1997) juga pernah melakukan penelitian mengenai hubungan antara wisdom dan life satisfaction dengan subjek individu berusia 58 sampai 82 tahun berjumlah 120 subjek. Hasilnya menunjukan bahwa wisdom (didefinisikan sebagai gabungan dari dimensi kognitif, reflektif, dan afektif) memiliki peran yang amat besar terhadap life satisfaction lansia, sedangkan kondisi objektif individu seperti usia, kesehatan, status sosial ekonomi, finansial, lingkungan dan keterlibatan sosial tidak terlalu berperan terhadap life satisfaction lansia dibandingkan dengan wisdom.

Penelitian ini ingin melihat peran wisdom terhadap life satisfaction dengan subjek lanjut usia berusia 60 tahun keatas. Hipotesis dalam penelitian ini adalah "Wisdom dapat memprediksi life satisfaction."

\section{Metode}

Partisipan penelitian ini berjumlah 65 yang semuanya adalah orang dewasa yang tinggal di Daerah Istimewa Yogyakarta (DIY) dengan usia yang bergerak antara 61 hingga 79 tahun $(M=65,44 ; S D=4,58)$. Jumlah partisipan yang berjenis kelamin wanita ( $\mathrm{N}=45 ; 69,2 \%)$ lebih banyak dibanding dengan pria ( $\mathrm{N}=20 ; 30,8 \%$ ). Tingkat pendidikan partisipan merata pada berbagai jenjang, dari SD hingga Perguruan Tinggi namun banyak didominasi oleh sekolah menengah atas (SMA). Tiga tingkat pendidikan dengan proporsi terbesar adalah SMA $(\mathrm{N}=30$; $46,2 \%), \mathrm{S} 1(\mathrm{~N}=9 ; 13,8 \%)$ dan D3 ( $\mathrm{N}=11$; $16,9 \%)$. Dari sisi profesi partisipan, sebagian besar partisipan adalah ibu rumah tangga. Hal ini juga berimplikasi pada status pernikahan partisipan ini adalah menikah.

Pengambilan data dilakukan melalui proses sampling non-random. Proses pemenuhan inform consent dilakukan secara verbal. Semua partisipan telah diberitahu mengenai penelitian ini beberapa konsekuensi keikutsertaannya. Semua partisipan dalam penelitian ini telah menyetujui penjelasan yang diberikan oleh pengambil data.

\section{Instrumen pengukuran}

Skala Life Satisfaction yang dipakai dalam penelitian dikembangkan oleh Neugarten et al. (1961) Skala ini memuat 26 aitem pernyataan dengan menggunakan format Likert lima opsi. Skala ini memiliki beberapa aspek antara lain kesenangan, keteguhan hati, keselarasan, konsep diri, dan suasana hati. Hubungan antar aspekaspek ini adalah sangat tinggi sehingga aspek-aspek ini bukan merupakan dimensi yang bersifat independen. Dengan adanya keterkaitan ini maka Skala Kepuasan hidup dapat menghasilkan satu skor tunggal yang dapat menjelaskan level kepuasan individu terhadap kehidupan yang dijalaninya.

Penelitian ini juga menggunakan skala Three Dimensional-Wisdom Scale (3D-WS) yang dikembangkan oleh Ardelt (2003). Skala ini terdiri dari 39 aitem pernyataan dengan menggunakan format Likert lima opsi. Skala ini memiliki beberapa dimensi antara lain dimensi kognitif, dimensi afektif, dan dimensi reflektif. 
Prosedur analisis data

Analisis data dalam penelitian ini dilakukan dengan menggunakan regresi linier berganda. Variabel yang ditetapkan sebagai prediktor adalah aspek-aspek dari variabel Wisdom serta beberapa variabel demografi (usia, jenis kelamin, tingkat pendidikan). Program lunak komputer yang dipakai untuk menganalisis adalah SPSS 18. Analisis regresi akan menghasilkan koefisien regresi yang menjelaskan harga prediksi setiap variabel bebas terhadap skor variabel dependen.

\section{Hasil}

\section{Statistik deskriptif}

Hasil analisis deskriptif ditunjukkan pada Tabel 1. Pada tabel tersebut dijelaskan statistik deskriptif untuk masing-masing variabel. Rerata masing-masing variabel cenderung tinggi karena harganya melebihi 3 (skor butir bergerak antara 1 hingga 4). Tingginya skor ini dapat dikarenakan oleh faktor usia partisipan yang semuanya adalah para lansia.

\section{Uji regresi}

Analisis dalam penelitian ini dilakukan dengan menggunakan regresi berganda (Lihat tabel 2). Analisis regresi dilakukan dilakukan dengan melibatkan variabel demografi sebagai variabel sertaan dalam analisis. Hasil analisis menemukan bahwa ada dua prediktor yang signifikan yaitu tingkat pendidikan $(b=0,124 ; p=0,039)$ dan aspek dari wisdom berupa afektif $(b=0,540 ; p=$ 0,003). Variabel tingkat pendidikan menjelaskan variansi di dalam kepuasan hidup sebesar 10 persen sedangkan wisdom pada aspek afektif menjelaskan varian sebesar 21 persen.

\section{Diskusi}

Penelitian ini ingin melihat peran wisdom terhadap life-satisfaction dengan subjek lanjut usia berusia 60 tahun keatas. Hipotesis dalam penelitian ini adalah "Wisdom dapat memprediksi lifesatisfaction". Hasil analisis menunjukan bahwa hipotesis penelitian ini diterima. Wisdom memiliki peran dalam menciptakan kepuasan hidup pada lansia. Hasil penelitian ini sesuai dengan hasil penelitian sebelumnya oleh Hayat, Khan, dan Sadia (2016). Wisdom berkontribusi terhadap kepuasan hidup lansia dengan perantara mediator berupa resiliensi (Hayat, Khan, dan Sadia, 2016).

Berdasarkan hasil penelitian ini, hanya satu dimensi wisdom yang secara signifikan memprediksi kepuasan hidup yaitu dimensi afektif. Dimensi afektif yakni kemampuan yang meliputi empati dan rasa saling menyayangi yang disertai dengan motivasi untuk menjaga perasaan orang lain membutuhkan transendensi selfcenteredness (Ardelt, 2003).

Lansia memiliki pengalaman hidup yang banyak, hal tersebut dapat

Tabel 1.

Statistik Deskriptif Skor Variabel Penelitian

\begin{tabular}{lllllllll}
\hline \multirow{2}{*}{ Variabel Penelitian } & \multirow{2}{*}{ Min } & \multirow{2}{*}{ Maks } & \multirow{2}{*}{ Rerata } & \multirow{2}{*}{ SD } & \multicolumn{3}{c}{ Skewness } & \multicolumn{2}{c}{ Kurtosis } \\
\cline { 7 - 10 } & & & & & & & & \\
& 2,63 & 4,17 & 3,27 & 0,35 & 0,12 & 0,30 & $-0,49$ & 0,60 \\
Wisdom Total & 2,08 & 4,33 & 2,99 & 0,52 & 0,34 & 0,30 & $-0,27$ & 0,60 \\
Wisdom Kognitif & 2,36 & 4,31 & 3,55 & 0,41 & $-0,26$ & 0,30 & $-0,07$ & 0,60 \\
Wisdom Afektif & 2,42 & 4,17 & 3,30 & 0,39 & $-0,44$ & 0,30 & $-0,10$ & 0,60 \\
Wisdom Reflektif & 1,00 & 3,69 & 3,06 & 0,45 & $-2,49$ & 0,32 & 8,23 & 0,63 \\
Kepuasan Hidup & & & & & & & &
\end{tabular}


Tabel 2.

Hasil Analisis Regresi

\begin{tabular}{lcccc}
\hline \multicolumn{1}{c}{ Variabel } & $\boldsymbol{b}$ & Eror Standar & Beta & $\boldsymbol{p}$ \\
\hline Konstanta & 2,113 & 1,170 & - & 0,077 \\
Usia & 0,000 & 0,014 & $-0,004$ & 0,976 \\
Jender & 0,014 & 0,123 & 0,015 & 0,909 \\
Pendidikan & 0,124 & 0,058 & 0,316 & 0,039 \\
Wisdom Kognitif & $-0,211$ & 0,150 & $-0,227$ & 0,167 \\
Wisdom Afektif & 0,540 & 0,174 & 0,494 & 0,003 \\
Wisdom Reflektif & $-0,223$ & 0,171 & $-0,180$ & 0,199 \\
\hline
\end{tabular}

digunakan untuk memberikan nasihat dan contoh-contoh bagi orang yang lebih muda. Pemberian nasihat tersebut merupakan perwujudan kasih sayang. Dengan kata lain, lansia merasa memiliki

peran dan harga diri dalam hidupnya, yang merupakan sumber kepuasan hidup (kepuasan hidup). Hal ini sejalan dengan tahap psikososial lansia menurut Erikson (1959). Pada masa ini lansia mengalami pergulatan antara integritas dan keputusasaan (Erikson, 1959). Ketika lansia menyadari bahwa dirinya telah berkontribusi kepada lingkungannya melalui nasihat-nasihat terkait pengalaman hidupnya atau merasa bahwa dirinya memiliki integritas, maka kepuasan hidupnya akan meningkat (Ardelt \& Jacobs, 2009).

Individu yang sukses melalui tahap pertentangan antara integritas dan keputusasaan juga cenderung menunjukkan karakter yang sama dengan individu dengan kebijaksanaan afektif. Lansia yang berhasil mencapai tahap kehidupan ini cenderung lepas dari sifat self-centredness (Ardelt, 2003). Mereka tidak lagi fokus terhadap hal-hal yang ingin mereka capai atau seharusnya telah mereka capai (Erikson, 1959). Akibatnya mereka dapat merasakan kepuasan hidup (Ardelt \& Jacobs, 2009).

Lansia yang menunjukkan wisdom afektif juga cenderung memiliki kualitas hubungan yang positif dengan individu- individu lain di sekitarnya. Hal ini dikarenakan ia mampu menunjukkan perasaan yang tulus terhadap orang lain sehingga orang lain merasa nyaman untuk berada di dekatnya (Ardelt, 2003). Diketahui bahwa hubungan sosial yang baik dengan lingkungan berkaitan dengan kepuasan hidup (Amati, Meggiolaro, Rivellini, \& Zaccarin, 2018).

Hasil analisis tambahan juga menemukan bahwa tingkat pendidikan juga dapat memprediksi tingkat kepuasan hidup lansia. Hal ini sejalan dengan hasil penelitian Gaymu dan Springer (2010) terhadap generasi lansia di Eropa. Partisipan dalam penelitian ini kebanyakan berpendidikan SMA ke atas. Lansia dengan tingkat pendidikan tersebut berpikir secara komprehensif. Lansia mampu memahami kehidupannya dan memiliki keinginan untuk mengetahui kebenaran. Lansia yang bisa memahami dirinya akan merasakan kepuasan dalam hidupnya (Gaymu \& Springer, 2010).

\section{Kesimpulan}

Kebijaksanaan merupakan prediktor dari kepuasan hidup lansia dengan dimensi afektif sebagai satu-satunya prediktor signifikan. Kebijaksanaan afektif ditemukan mampu meningkatkan kualitas hubungan sosial lansia dengan lingkungan serta menciptakan perspektif positif lansia terhadap kehidupan dan dirinya sendiri. 
Akibat-akibat dari kebijaksanaan afektif tersebutlah yang menimbulkan kepuasan hidup pada lansia. Hal ini mengindikasikan bahwa kebijaksanaan afektif sendiri kemungkinan tidak berkontribusi secara langsung terhadap kepuasan hidup lansia.

\section{Saran}

Peneliti selanjutnya dapat meneliti variabel-variabel yang terkait dengan kebijaksanaan afektif dan kepuasan hidup. Berdasarkan kajian literatur, terdapat kemungkinan bahwa ada variabel mediasi yang menghubungkan kedua variabel tersebut.

\section{Daftar Pustaka}

Amati, V., Meggiolaro, S., Rivellini, G., \& Zaccarin, S. (2018). Social relations and kepuasan hidup: The role of friends. Genus, 74(1). doi: 10.1186\%2Fs41118-018-0032-Z

Ardelt, M. (1997). Wisdom and kepuasan hidup in old age. The Journals of Gerontology: Series B: Psychological Sciences and Social Sciences, 52(1), 1527. doi: 10.1093/geronb/52B.1.P15

Ardelt, M. (2003). Empirical assessment of a three-dimensional wisdom scale. Research on Aging, 25(3), 275-324. doi: 10.1177\%2F0164027503025003004

Ardelt, M. (2005). How wise people cope with crises and obstacles in life. ReVision, 28(1), 7-19.

Ardelt, M., \& Jacobs, S. (2009). Wisdom, integrity, and kepuasan hidup in very old age. In M. C. Smith \& N. DeFrates-Densch (Eds.), Handbook of research on adult learning and development (pp. 732-760). New York, NY, US: Routledge/Taylor \& Francis Group.

Asadi, S., Amiri, S., Molavi, H., \& Noaparast, K.B. (2012). A crosssectional study of self reported wisdom development: from adolescence through adulthood. Interdiciplinary Journal of Contemporary Research in Business, $4(2), 482-492$.

Azwar, S. (2013). Sikap manusia dan pengukurannya. Yogyakarta: Pusat Belajar Offset.

Badan Pusat Statistik (2010). Laporan Sosial Indonesia 2010: Kajian Indikator Kesehatan. Diunduh dari https://www.bps.go.id/publication/d ownload.html

Berg, A. I. (2008). Kepuasan hidup in Late Life. Sweden: Gothenburg.

Bergsma, A., \& Ardelt, M. (2012). Selfreported wisdom and happiness: an empirical investigation. Journal of Happiness Studies 13: 481-499.

Birren, J. E., \& Svensson, C. M. (2005). Wisdom in History. In R. J. Sternberg \& J. Jordan (Eds.), A handbook of wisdom: Psychological perspectives (pp. 3-28).

Diener, E., Emmons, R. A., Larsen, R. J., \& Griffin, S. (1985). The satisfaction with life scale. Journal of Personality Assessment, 49, 71-75. doi: 10.1207/s15327752jpa4901 13

Diener E., Suh, E. M., Lucas, R. E., \& Smith, H. L. (1999). Subjective well-being: Three decades of progress. Psychological Bulletin, 125(2), 276-302. doi: $10.1037 / 0033-2909.125 .2 .276$

Erikson, E. H. (1959). Identity and the life cycle. New York: International University Press.

Gaymu, J. \& Springer, S. (2010). Living conditions and kepuasan hidup of older Europeans living alone: A gender and cross-country analysis. Ageing \& Society, 30, 1153-1175. doi: 10.1017/S0144686X10000231

Glück, J., \& Bluck, S. (2011). Laypeople's conceptions of wisdom and its development: cognitive and integrative views. The Journals of 
Gerontology: Series B, 66B(3), 321-324. doi: $10.1093 /$ geronb/gbr011

Hayat, S.Z., Khan, S., \& Sadia, R. (2016). Resilience, wisdom, and kepuasan hidup in elderly living with families and in old-age homes. Pakistan Journal of Psychological Research, 31(2), 475-494.

Hurlock. (1999). Psikologi perkembangan: Suatu pendekatan sepanjang rentang kehidupan (Trans). Jakarta: Erlangga.

Jeste, D. V., Ardelt, Monika., Blazer, Dan., Kraemer, H. C., Vaillant, George., \& Meeks, T. W. (2010). Expert consensus on characteristics of wisdom: A delphi method study. The Gerontologist, 50(5), 668-680. doi: 10.1093\%2Fgeront\%2Fgnq022

Monks, F. J., Knoers, A. M. P., \& Haditono, S. R. (2004). Psikologi perkembangan pengantar dalam berbagai bagiannya. cetakan ke-11. Yogyakarta: Gadjah Mada University Press.

Neugarten, B. L., Havighurst, R. J., \& Tobin, S. S. (1961). The measurement of kepuasan hidup. Journal of Gerontology, 16(2), 134-143. doi: 10.1093/geronj/16.2.134

Neugarten, B. L., Havighurst, \& Tobin, S. S. (1968). Personality and patterns of aging. In Neugarten (Ed.), Middle age and aging (pp. 173-180). Chicago: University of Chicago Press.
Papalia, D., Olds., S., \& Feldman, R. (2007). Human development (Edisi kesepuluh). New York: McGraw Hill. Companies.

Santrock, J. W. (2002). Life-span development. New York: McGraw-Hill.

Saul, L. J., \& Pulver, S. E. (1965). The concept of emotional maturity. Comprehensive Psychiatry, 6(1), 6-20. doi: 10.1016/S0010440X(65)80003-7

Sirgy, M.J. (2012). The psychology of quality of life: Hedonic well-being, kepuasan hidup, and eudaimonia. New York: Springer.

Snyder, C. R., \& Lopez, S.C. (2007). Positive psychology: The scientific and practical explorations of human strengths. New Delhi: Sage Publications, Inc.

Stenberg. (1986). Intelligence, wisdom, and creativity: Three is better than one. Educational Psychologist, 21(3), 175190. doi: $10.1207 / \mathrm{s} 15326985 \mathrm{ep} 21032$

Trief, T. M., Michael J. W., Pine, D. S., \& Weinstock. (2003). Comparison of health-related quality of life of elderly and younger insulin-treated adults with diabetes. Journal of Age and Aging, 32(6), 613-618. doi: 10.1093/ageing/afg105

Wirakusumah, S. E. (2002). Tetap bugar di usia lanjut. Jakarta: Imbus Agri Widya 